\title{
Study of Vasodilating and Regenerative Effect of the Gel with Nettle Juice intended for Telogen Effluvium Treatment
}

\author{
Fedorovska Maryana Ivanivna', Polovko Natalia Petrivna², Fedenko Svitlana Mykolaivna', Antymys Olga Vasylivna ${ }^{3}$ \\ 'Organization and Economics in Pharmacy and Drug Technology Department, Ivano-Frankivsk National Medical University, Ukraine. \\ '2 Pharmaceutical Technology of Drugs Department, National University of Pharmacy, Kharkiv c., Ukraine. \\ ${ }^{3}$ Human Anatomy Department, Ivano-Frankivsk National Medical University, Ukraine.
}

\section{ARTICLE INFO \\ Article history: \\ Received on: $21 / 11 / 2017$ \\ Accepted on: 08/01/2018 \\ Available online: 28/01/2018}

Telogen effluvium, gel with nettle juice, vasodilating effect, follicle-stimulating activity.

\section{Key words:}

\begin{tabular}{l}
\hline ABSTRACT \\
\hline Telogen effluvium remains the most common diffuse hair loss in women which influences the quality of their life. \\
Stinginag nettle leaves and stems contain a wide range of biologically active substances which stimulate the metab- \\
olism and trophic processes in hair follicle cells. The purpose of the research was to study the vasodilating effect \\
and follicle-stimulating activity of the gel with nettle juice in rats under conditions of wool shedding induced by \\
orally administered boric acid. Thus, conducted pharmacological studies indicated that the gel in comparison with \\
the untreated animals accelerated the wool growth in rats, improved its quality by increasing the weight and reducing \\
the percentage of dystrophic hairs. Histological studies confirmed that cutaneous application of the gel significantly \\
dilated the vessels in the dermis reticular layer. The intensification of blood supply was confirmed by an increase in \\
the number of mast cells and their active degranulation. Strengthening of blood circulation caused the increase of the \\
hair follicle quantity in the active anagen phase.
\end{tabular}

\section{INTRODUCTION}

The prevention and treatment of Telogen effluvium (TE) remains the important task of modern medicine. TE is the most common diffuse hair loss in women of reproductive age, which is due to concomitant somatic pathology (disorders and diseases of the gastrointestinal tract and the endocrine system, infectious diseases, etc.) and/or negative exogenous factors (inappropriate nutrition, drug intoxication, stress, inappropriate hair care, etc.) (Shrivastava, 2009). Hair follicles (HF) affected by harmful factors are characterized with anagen (active growth) termination, which results in the onset of catagen (hair involution) and subsequently 2-3 months telogen (resting phase) finishing with exogen - dead hair shedding (Figure 1) (Harrison and Bergfeld, 2009).

In the TE therapy plants remedies occupy the important

${ }^{*}$ Corresponding Author

Maryana Fedorovsk; Organization and Economics in Pharmacy and

Drug Technology Department, Ivano-Frankivsk National Medical University, 124 k, Galytska Str., Ivano-Frankivsk, Ukraine, 76008.

E-mail:maryana@fedorovska.com place (Patil et al., 2010; Kaushik et al., 2011). Plant biologically active substances (BAS) with vasodilation, capillary protective, epithelial cells regenerating effects, microelements, amino acids, vitamins and other nutrients for HF tissues saturation are widely used (Lourith and Kanlayavattanakul, 2013; Semwal et al., 2015).

From olden times in medicine and cosmetology stinging nettle (Urtica dioica L.) was used for renovation and hair growth stimulation. Nettle leaves and stems contain a wide range of BAS: organic (formic, pantothenic) and hydroxy cinnamic (chlorogenic, caffeic, ferulic) acid, flavonoids (routine, quercetin, campherol), chlorophyll, organically bound silicon, a complex of vitamins $\left(\mathrm{K}_{1}\right.$, carotenoids, vitamins $\mathrm{C}, \mathrm{B}_{1}, \mathrm{~B}_{2}, \mathrm{~B}_{6}$, etc.) and other BAS (amines, amino acids, macro and microelements). The listed BAS enhance blood circulation in the skin capillary system, stimulate the metabolism and trophic processes, exhibit regenerative properties of HF cells, therefore the remedies with stinging nettle (infusions, tinctures, lotions, masks, juices, etc.) are used for the TE prevention and treatment (Gülçin et al., 2004; Bhuwan et al., 2014; Mal Ait Haj Said et al., 2015). 


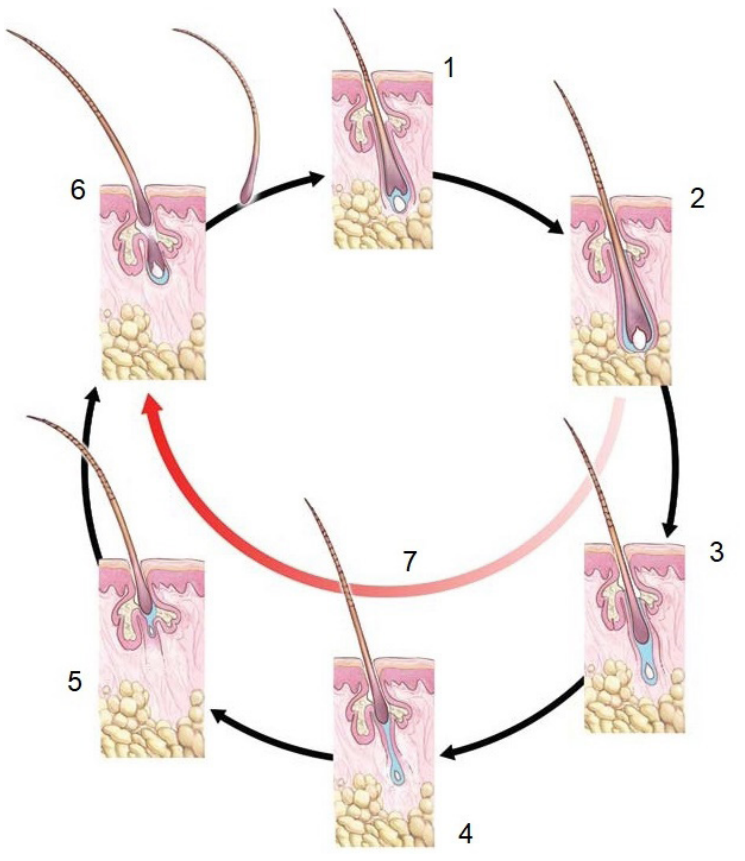

Fig. 1: The hair cycle and telogen effluvium (Harrison and Bergfeld, 2009; medical illustrator: William Garriott). 1,2 - anagen phase (active hair growth, 2-8 years), 3,4 - catagen phase (involution, 4-6 weeks), 5 - telogen phase (resting, 2-3 months), 6 - exogen phase (release of dead hair), 7 - telogen effluvium (anagen termination, noticeable increase in hair shedding occurs 2 to 3 months after hair was affected).

The technological, rheological and microbiological studies were carried out, which resulted in the development of the medical cosmetic gel with nettle juice intended for TE therapy (Fedorovska et al., 2015; Fedorovska and Polovko, 2016). Purpose of the given research was to study the vasodilating effect and follicle-stimulating activity of the developed gel with nettle juice in rats under conditions of wool shedding induced by orally administered boric acid (Belenichev et al., 2008).

\section{MATERIAL AND METHODS}

\section{Preparation of nettle juice}

Nettle fresh upper parts of the stems with 5-6 leaves were collected at the end of May in Ivano-Frankivsk region (Ukraine). Technological process of nettle juice preparation included the following stages: grinding of fresh raw materials, pressing, re-grinding and pressing, inactivation of enzymes in raw juice with $20 \mathrm{~min}$ heating in a water bath at $40-60^{\circ} \mathrm{C}$, preservation with $96 \%$ ethanol in quantity of $15 \%$ by weight, sedimentation at $2-4^{\circ} \mathrm{C}$ in a refrigerator for 10 days, filtration, packaging, labeling. Obtained juice was a dark brown transparent liquid with a specific smell; density ranging from 0.994 to $1.106 \mathrm{~g} / \mathrm{ml} ; \mathrm{pH}$ from 6.5 to 7.0 ; dry residue at least $3.5 \%$; identification (thin layer chromatography method) and quantitative determination (spectrophotometric method): hydroxyl cinnamic acids at least $0.01 \%$, carotenoids at least $0.002 \%$, chlorophyll at least $0.003 \%$ (Fedorovska et al., 2015).

\section{Preparation of gel with nettle juice}

The remedy containing $15 \%$ per weight of the nettle juice in a gel base was prepared. Briefly, combine carbopol-so- dium alginate gel base was prepared firstly. Potassium sorbate was used as a carbopol neutralizer as well as a gel preservative, glycerol was used as a sodium alginate solubilizer as well as a moisturizer, purified water was used as a solvent (Fedorovska and Polovko, 2016). After weighing, the nettle juice was added in the gel base by continuous mixing at room temperature.

\section{Experimental animals}

White non-linear rats of both sexes with weight range of 200-250 g were obtained from the vivarium of Ivano-Frankivsk State Medical University. All experimental protocols were approved by the Ethical Committee of the University (Minutes No. 69/13, dated 2013.12.03). Animals were kept under standard vivarium conditions, they received food and water ad libitum.

\section{Experimental design}

All 28 rats were weighed and tagged; growth destruction of animal wool was induced with oral administration of boric acid $(5 \mathrm{mg} / \mathrm{kg})$ during 14 days, then wool was completely shaved on the back section $(3 \times 7 \mathrm{~cm})$. After that all rats were randomly divided into four groups of seven animals each as followed: 1st group - intact animals; $2^{\text {nd }}$ group - untreated; $3^{\text {rd }}$ group - treated with a comparison drug (Alloton spray: complex tincture (1:5) from a mixture of Arctium lappa L. roots $-5.6 \mathrm{~g}$, Sophora japonica L. fruit $-5.6 \mathrm{~g}$, Acorus calamus L. rhizome $-3.2 \mathrm{~g}$, Urtica dioica L. leaves $-2.8 \mathrm{~g}$; Humbus lupulus cones $-2.8 \mathrm{~g}$ ); $4^{\text {th }}$ group - treated with the prepared gel. The developed medical cosmetic remedy and the comparison drug were applied on the shaved back of the rats at the maximum technically spreading dose (app. $1.0 \mathrm{~g}$ of the developed gel; 3-4 pulverizations of Alloton spray) during next 14 days.

\section{Analytical methods}

According to the experiment, the wool length was daily monitored during 14 days. After that period, new wool was completely cut and weighed on scales. The percentage of dystrophic wool (presence of hairs with pointed tip) was observed and determined with help of a microscope "Delta Optical Genetic Pro" with built-in camera: lens 40/0.65 160/0.17; eyepiece WF 10×/18). Additionally, from each group one animal was randomly selected and subjected to euthanasia with compliance of the bioethics; skin biopsy was applied to the chosen animals. The vascular net in different layers of the skin, follicular density (number of follicles per unit area) and hair growth phase (anagen) were estimated.

The study of the vascular net was carried out by the injection method using an ether-chloroform mixture of Paris blue ( $10 \mathrm{~g}$ of substance per $100 \mathrm{ml}$ of a solvent consisting of ether and chloroform in a ratio of 3:1). Fuchseline-picrofuchsine was used for histological examination of the vascular wall, the study of skin structures was carried out with the hematoxylin and eosin staining. The number of hair follicles was determined by morphometric analysis. All histological experiments were performed at the Human Anatomy Department of Ivano-Frankivsk State Medical University according to standard techniques (Bagrij, 2016; Titford, 2009; Kiernan, 2015). The electronic microscopic photographs were made with an electron microscope PEM-125 $\mathrm{K}$ at magnifications of 8000-10000 and an accelerating voltage of $75 \mathrm{kV}$ with subsequent photographing; microscopic photo- 
graphs were made with the microscope "Delta Optical Genetic Pro".

\section{Statistical analysis}

The data of external estimations (given in Tables 1-2) were analyzed as the mean \pm SEM for seven animals in each group. The data of histological studies (vascular lumen diameter, the number of hair follicles per $1 \mathrm{~mm}^{2}$ ) were studied as the mean \pm SEM for ten skin samples of each selected animal. Statistical analyses were performed using one-way analysis of variance (ANOVA). Differences were considered to be statistically significant when $\mathrm{P}$ was $<0.05$. All statistical analyses were performed with MS Excel.

\section{RESULTS AND DISCUSSION}

The results of the developed gel influence on the growth stimulating activity of the rats' wool are presented in Tables 1-2.

According with the data in Table 1, the developed gel stimulated the recovery of damaged HF growth and slightly exceeded "Alloton" in terms of regenerative action. Thus, wool began to grow on the $3^{\text {rd }}$ day of the experiment in the $1^{\text {st }}, 3^{\text {rd }}$ and $4^{\text {th }}$ groups, but in the $2^{\text {nd }}$ group (untreated animals) - on the $4^{\text {th }}$ day. Intensive wool growth in the intact ( $1^{\text {st }}$ group) and the treated ( $3^{\text {rd }}$ and $4^{\text {th }}$ group) animals was observed on the $5-8^{\text {th }}$ days of the research. On the $14^{\text {th }}$ day of the experiment, the difference in the wool length in the experimental $4^{\text {th }}$ group was exceeded $3 \mathrm{~mm}$ in comparison with the untreated $2^{\text {nd }}$ group.

On the $15^{\text {th }}$ day of the experiment (Table 2) the wool weight from the shaved area of $4^{\text {th }}$ group (experimental animals) was $\approx 480 \mathrm{mg}$, which significantly exceeded the wool weight of the non-treated $2^{\text {nd }}$ group $(\approx 371 \mathrm{mg})$. The wool weight of the healthy animals in the 1 st group was slightly higher $(\approx 500 \mathrm{mg})$, and in the $3^{\text {rd }}$ group (rats treated with "Alloton") at approximately the same level $(\approx 472)$. The experimental 4th group also showed a decrease in the percentage of dystrophic wool compared to the untreated animals. So the amount of dystrophic wool in the healthy animals was $\approx 10 \%$, in the experimental 4 th group $-\approx 17 \%$, and in the untreated animals $-\approx 38 \%$ (Table 2 ).

Table 1: The influence of the developed gel with nettle juice on the experimental animal wool growth $(\mathrm{mm})$.

\begin{tabular}{ccccc}
\hline Day & $\begin{array}{c}\text { Intact rats } \\
\left(\mathbf{1}^{\text {st }} \text { group }\right)\end{array}$ & $\begin{array}{c}\text { Untreated } \\
\text { rats } \\
\left(\mathbf{2}^{\text {nd }} \text { group }\right)\end{array}$ & $\begin{array}{c}\text { Rats treated } \\
\text { with “Alloton" } \\
\left(\mathbf{3}^{\text {rd }} \text { group }\right)\end{array}$ & $\begin{array}{c}\text { Rats treated with } \\
\text { developed gel } \\
\left.\mathbf{4}^{\text {th }} \text { group }\right)\end{array}$ \\
\hline 2 & - & - & - & - \\
3 & $1.0 \pm 0.07$ & - & $1.0 \pm 0.06$ & $1.0 \pm 0.05$ \\
4 & $2.0 \pm 0.07$ & $1.0 \pm 0.07$ & $1.8 \pm 0.06$ & $2.0 \pm 0.04$ \\
5 & $3.1 \pm 0.07$ & $1.9 \pm 0.01$ & $2.7 \pm 0.06$ & $3.1 \pm 0.04$ \\
8 & $6.6 \pm 0.06$ & $3.7 \pm 0.10$ & $6.4 \pm 0.01$ & $6.7 \pm 0.06$ \\
10 & $7.7 \pm 0.07$ & $5.3 \pm 0.07$ & $7.2 \pm 0.06$ & $7.8 \pm 0.04$ \\
14 & $9.8 \pm 0.05$ & $6.5 \pm 0.05$ & $8.9 \pm 0.05$ & $9.7 \pm 0.06$ \\
\hline
\end{tabular}

$*_{-}(\mathrm{p}<0.05)$ in relation to the 2 nd group (untreated rats).

Table 2: Influence of the developed gel on the quality and structure of the rat wool.

\begin{tabular}{lcccc}
\hline Characteristic & $\begin{array}{c}\text { Intact rats } \\
\left(\mathbf{1}^{\text {st }} \text { group }\right)\end{array}$ & $\begin{array}{c}\text { Untreated } \\
\text { rats } \\
\left(\mathbf{2}^{\text {nd }} \text { group }\right)\end{array}$ & $\begin{array}{c}\text { Rats treated } \\
\text { with “Alloton" } \\
\left(\mathbf{3}^{\text {rd }} \text { group }\right)\end{array}$ & $\begin{array}{c}\text { Rats treated with } \\
\text { developed gel } \\
\left(\mathbf{4}^{\text {th }} \text { group }\right)\end{array}$ \\
\hline $\begin{array}{l}\text { Wool weight } \\
\text { from shaved } \\
\text { area, mg }\end{array}$ & $499.2 \pm 6.8$ & $370.5 \pm 9.8$ & $472.0 \pm 8.7$ & $480.3 \pm 9.3^{*}$ \\
$\begin{array}{l}\text { \% of the dystro- } \\
\text { phic wool }\end{array}$ & $10.32 \pm 0.38$ & $37.72 \pm 2.15$ & $19.51 \pm 1.05$ & $16.87 \pm 0.90^{*}$ \\
\hline
\end{tabular}

$*_{-}(\mathrm{p}<0.05)$ in relation to the 2 nd group (untreated rats).

The performed studies confirmed that the external application of the developed gel caused the significant changes in both histological and ultrastructural organization of subcapillary and dermal arterial nets. However, changes in the dermal arterial network were more distinct and accompanied by enlargement of the capillary lumen and by the vascular wall thickening (Figure 2).

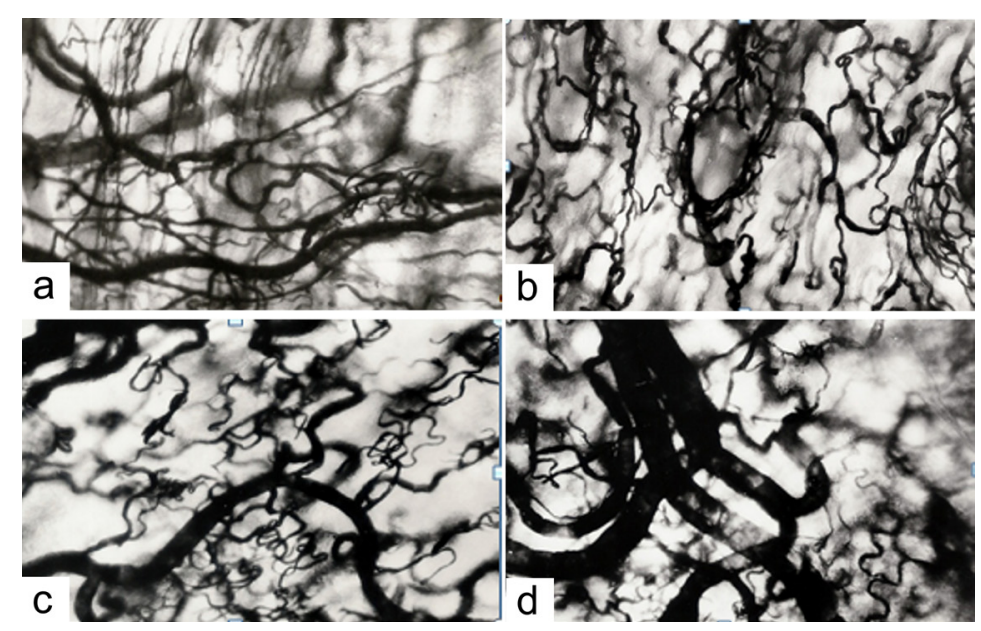

Fig. 2: Dermal arterial net of white rats' skin samples: $a-1^{\text {st }}$ group; $b-2^{\text {nd }}$ group; $c-3^{\text {rd }}$ group; $d-4^{\text {th }}$ group. Vessels injection with Paris blue; an increase in 400 .

The widest vascular lumen (diameter $=76.45 \pm 0.42$ $\mu \mathrm{m})$ was in the skin samples of the $4^{\text {th }}$ group after developed gel application (Figure $2 \mathrm{~d}$ ). The vessels in the skin samples of $1^{\text {st }}$ group had a diameter of $69.85 \pm 0.25 \mu \mathrm{m}$ (Figure 2 a). The skin of animals treated with "Alloton" was characterized by a less distinct vascular pattern (Figure $2 \mathrm{c}$ ). 
Near the dermal vessels of the $4^{\text {th }}$ experimental group the number of mast cells significantly increased, which were in a state of strong degranulation (Figure 3). Particularly strongly degranulated mast cells were seen in the reticular layer of the dermis. On the ultrastructure level it was observed a significant decrease of the mast cells size and granules that went beyond their edges (Figure $3 \mathrm{~b}$ ). High degranulation of mast cells and their functional activity is a factor of changes in blood vessels, which indicate the intensification of blood circulation in the skin.

When applying the gel with nettle juice, a significant increase in the number of new hair follicles was noted (Figure 4).

The number of follicles in the stage of anagen in skin

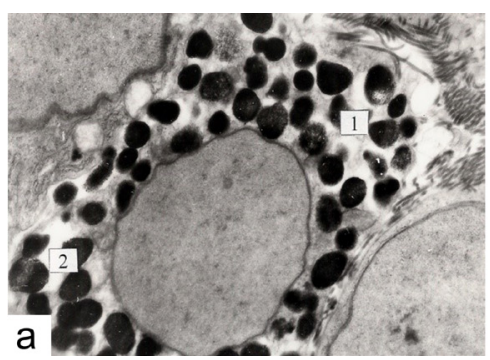

samples of $4^{\text {th }}$ group was $93 \%$ (compared with: $1^{\text {st }}$ group $-87 \%$; $2^{\text {nd }}$ group $-74 \% ; 3^{\text {rd }}$ group $-88 \%$ ). Also, the intensification of the HF epithelial cells proliferative activity was observed (Figure 5).

HF density per unit area $\left(1 \mathrm{~mm}^{2}\right)$ in the skin samples was determined with the morphometric analysis. The HF number in the $1^{\text {st }}$ group was $36.34 \pm 0.14$, in the $2^{\text {nd }}$ group $-21.98 \pm 0.23$, in the $3^{\text {rd }}$ group $-34.56 \pm 0.21$, in the $4^{\text {th }}$ group $-37.23 \pm 0.19$. As can be seen from the study results, the application of the developed gel in the experimental animals strongly stimulated HF genesis compared to the untreated rats. The samples of rats' skin tissues from each group are represented in Figure 6 for visual comparison of the HF quantity.

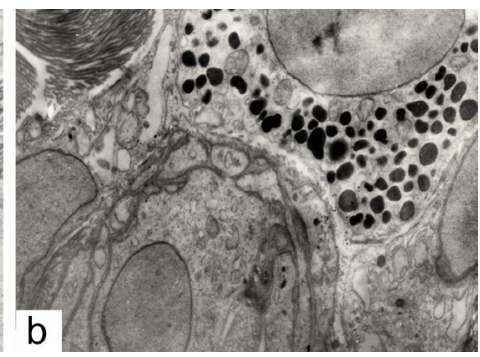

Fig. 3: Ultrastructure of the rats' skin mastocytes in the dermal papillary layer (1,2 - granules of different maturity degrees): $a-1^{\text {st }}$ group; $b-4^{\text {th }}$ group. Electronic microscopic photographs; an increase in 10000.

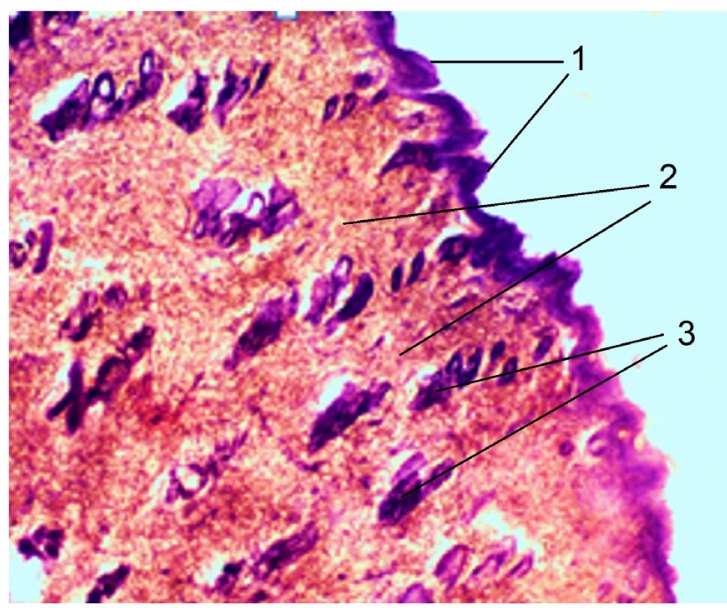

Fig. 4: A significant amount of hair follicles in the skin of the white rat after the application of gel with nettle juice: 1 - epidermis, 2 - dermis, 3 - hair follicles. Coloring with hematoxylin and eosin; microscopic photograph; an increase in 100.
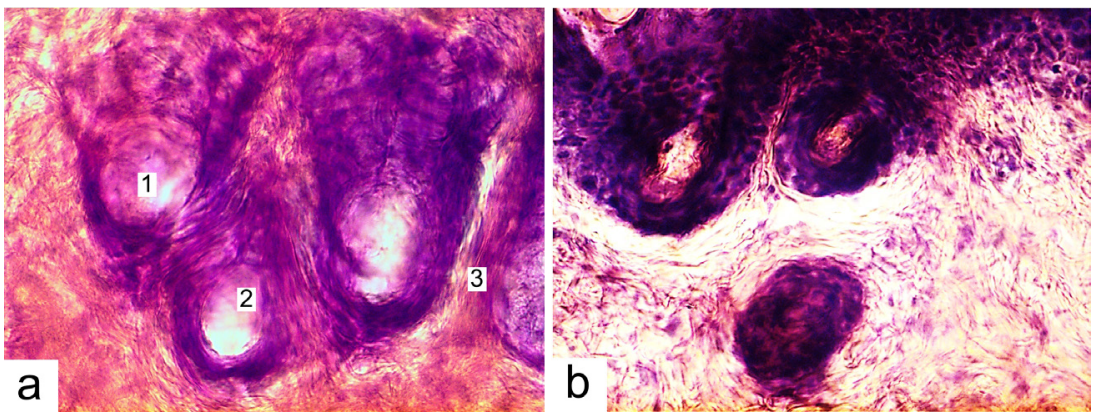

Fig. 5: The structure of the outer and inner epithelial sheath of the white rat HF ( 1 - root, 2 - internal epithelial sheath, 3 - external epithelial sheath): a - ${ }^{\text {st }}$ group; $\mathrm{b}-4^{\text {th }}$ group. Coloring with hematoxylin and eosin; microscopic photographs; an increase in 400 


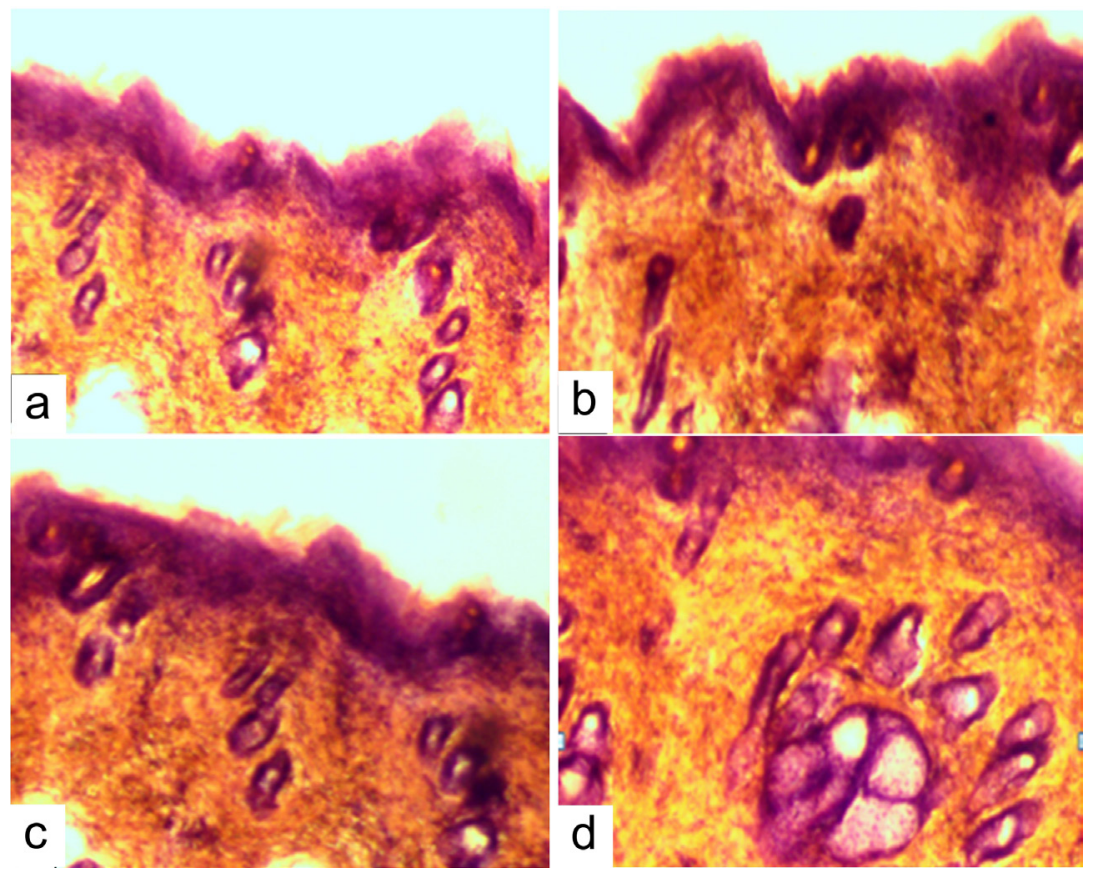

Fig. 6: Hair follicles in the skin of white rats: $\mathrm{a}-1^{\text {st }}$ group; $\mathrm{b}-2^{\text {nd }}$ group; $\mathrm{c}-3^{\text {rd }}$ group; $\mathrm{d}-4^{\text {th }}$ group. Coloring with hematoxylin and eosin; microscopic photographs; an increase in 200 .

\section{CONCLUSION}

Thus, conducted pharmacological and histological studies indicated that the developed gel with nettle juice in comparison with the untreated animals accelerated the wool growth renovation in rats, improved its quality by increasing the weight and reducing the percentage of dystrophic hairs.

It was proved that cutaneous application of the gel had biological effect that significantly dilated the vessels in the reticular layer of the dermis. The intensification of HF blood supply was confirmed by an increase in the number of mast cells and their active degranulation. Strengthening of blood circulation caused the increase of the epithelial cells growth and HF number in the active phase (anagen).

\section{REFERENCES}

Shrivastava SB. Diffuse hair loss in an adult female: Approach to diagnosis and management. Indian Journal of Dermatol. Venereol. Leprol, 2009; 1: 20-28.

Harrison S, Bergfeld W. Diffuse hair loss: its triggers and management. Cleveland Clinic Journal of Medicine, 2009; 76 (6): 361 367.

Patil SM, Sapkale GN, Surwase US, Bhomble BT. Herbal medicines as an effective therapy in hair loss - a review. Research Journal of Pharmaceutical, Biological and Chemical Sciences, 2010; 1: $773-781$.

Kaushik R, Gupta D, Yadav R. Alopecia: herbal remedies. Intern. Journal of Pharmaceutical Science and Research, 2011; 2(7): 1631-1637.

Lourith N, Kanlayavattanakul M. Hair loss and herbs for treatment. Journal of Cosmetic Dermatology, 2013; 12: 210-222.

Semwal D, Kotiyal R, Chauhan A et al. Alopecia and the herbal drugs: an overview of the current status. Advances in Biomedicine and Pharmacy, 2015; 2 (6): 246-254.
Gülçin I, Küfrevio ÖI, Oktay M, Büyükokuro ME. Antioxidant, antimicrobial, antiulcer and analgesic activities of nettle (Urtica dioica L.). Journal of Ethnopharmacology, 2004; 90: 205-215.

Bhuwan CJ, Minky M, Ajudhia NK. Pharmacognostical review of Urtica dioica L. International Journal of Green Pharmacy, 2014; October-December: 201-209.

Mal Ait Haj Said, Ibrahim Sbai el Otmani, Sanae Derfoufi, Adnane Benmoussa. Highlights on nutritional and therapeutic value of stinging nettle (Urtica dioica). International Journal of Pharmacy and Pharmaceutical Sciences, 2015; 7 (10): 8-14.

Fedorovska M, Polovko N, Kovpak L. Technological research and standardization of nettle juice in the process of the herbal remedy development for hair loss treatment. Clinical Pharmacy, Pharmacotherapy and Medical Standardization, 2015; 3-4: 114-119.

Fedorovska M, Polovko N. Development of the composition of the gel base for treating telogen effluvium. News of Pharmacy, 2016; 4 (88): 38-42.

Belenichev IF, Gladyshev VV, Abramov AV, Burlaka BS, Pavlov SV, Gorbachova SV. The study of groth stimulative and follicle protection actions of parapharmaceutical gel with bishofit. Zaporozhskiy Meditsinskiy Zhurnal, 2008; 3: 105-108.

Bagrij MM. Methods of morphological research. Nova knyga, 2016; 295.

Titford M. Progress in the development of microscopical techniques for diagnostic pathology. The Journal of Histotechnology, 2009; 32 (1): 9-19.

Kiernan JA. Histological and Histochemical Methods: Theory and Practice. 5th edition. Scion Publishing, 2015; 571.

How to cite this article:

Ivanivna FM, Petrivna PN, Mykolaivna FS, Vasylivna AO. Study of Vasodilating and Regenerative Effect of the Gel with Nettle Juice intended for Telogen Effluvium Treatment. J App Pharm Sci, 2018; 8 (01): 093-097. 